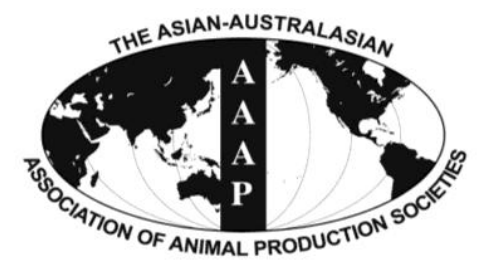

Asian Australas. J. Anim. Sci.

Vol. 26, No. 7 : 961-970 July 2013

http://dx.doi.org/10.5713/ajas.2013.13059

www.ajas.info

pISSN $1011-2367$ elSSN 1976-5517

\title{
Evaluation of Coarsely Ground Wheat as a Replacement for Ground Corn in the Diets of Lactating Dairy Cows
}

\author{
Y. Q. Guo ${ }^{a}$, Y. Zou ${ }^{\text {a }}$ Z. J. Cao, X. F. Xu, Z. S. Yang, and S. L. Li* \\ State Key Laboratory of Animal Nutrition, College of Animal Science and Technology, \\ China Agricultural University, Beijing, 100193, China
}

\begin{abstract}
Eight multiparous Holstein cows (569 $\pm 47 \mathrm{~kg}$ of BW; $84 \pm 17 \mathrm{DIM})$ were used to evaluate the effects of different levels of coarsely ground wheat $(\mathrm{CGW})$ as replacements for ground corn (GC) in diets on feed intake and digestion, ruminal fermentation, lactation performance, and plasma metabolites profiles in dairy cows. The cows were settled in a replicated $4 \times 4$ Latin square design with 3-wk treatment periods; four cows in one of the replicates were fitted with rumen cannulas. The four diets contained $0,9.6,19.2$, and 28.8\% CGW and 27.9, 19.2, 9.6, and 0\% GC on dry matter (DM) basis, respectively. Increasing dietary levels of CGW, daily DM intake tended to increase quadratically $(\mathrm{p}=0.07)$; however, apparent digestibility of neutral detergent fiber (NDF) and acid detergent fiber (ADF) were significantly decreased $(\mathrm{p}<0.01$ ) in cows fed the $28.8 \% \mathrm{CGW}$ diets. Ruminal $\mathrm{pH}$ remained in the normal physiological range for all dietary treatments at all times, except for the $28.8 \% \mathrm{CGW}$ diets at $6 \mathrm{~h}$ after feeding; moreover, increasing dietary levels of $\mathrm{CGW}$, the daily mean ruminal $\mathrm{pH}$ decreased linearly $(\mathrm{p}=0.01)$. Increasing the dietary levels of CGW resulted in a linear increase in ruminal propionate $(\mathrm{p}<0.01)$ and ammonia nitrogen $\left(\mathrm{NH}_{3}-\mathrm{N}\right)(\mathrm{p}=0.06)$ concentration, while ruminal acetate: propionate decreased linearly $(\mathrm{p}=0.03)$ in cows fed the $28.8 \%$ CGW diets. Milk production was not affected by diets; however, percentage and yield of milk fat decreased linearly $(\mathrm{p}=0.02)$ when the level of CGW was increased. With increasing levels of dietary CGW, concentrations of plasma beta-hydroxybutyric acid (BHBA) $(\mathrm{p}=0.07)$ and cholesterol $(\mathrm{p}<0.01)$ decreased linearly, whereas plasma glucose $(\mathrm{p}=0.08)$, insulin $(\mathrm{p}=0.02)$ and urea nitrogen $(\mathrm{p}=0.02)$ increased linearly at $6 \mathrm{~h}$ after the morning feeding. Our results indicate that CGW is a suitable substitute for GC in the diets of dairy cows and that it may be included up to a level of $19.2 \%$ of DM without adverse effects on feed intake and digestion, ruminal fermentation, lactation performance, and plasma metabolites if the cows are fed fiber-sufficient diets. (Key Words: Dairy Cows, Digestion, Lactation, Plasma Metabolites, Rumen Fermentation, Wheat)
\end{abstract}

\section{INTRODUCTION}

A rapid growth in the the corn ethanol industry has created a need for alternatives to corn grains for lactating dairy cows. Traditionally, wheat is primarily used for human food due to its high nutritive value. However, there is always a great deal of poor-quality (non-moldy) wheat not fit for human consumption or surplus wheat available in some areas, which can be used as an alternative feed for lactating dairy cows if the other feed grains are insufficient or if the price is too high.

The data show that both wheat and corn contain large amounts of starch (77\% vs $72 \%$, respectively) (Huntington, 1997), but they differ in the proportion of starch digested in

\footnotetext{
* Corresponding Author: Shengli Li. Tel: +86-(10)-62731254, Fax:+86-(10)-62731254, E-mail: lisheng0677@163.com

a These authors contribute equally to this work.

Submitted Jan. 22, 2013; Accepted Apr. 3, 2013; Revised Apr. 11, 2013
}

the rumen. Less than $10 \%$ of wheat starch remains undegraded in the rumen, but $40 \%$ of corn starch remains undegraded (Orskov, 1986). Increasing ruminally available energy content in the diets of dairy cows has the potential for improved efficiency of nutrient utilization in the rumen and increased microbial protein yield, which would enhance the milk production through increased metabolizable nutrient supply (Gozho and Mutsvangwa, 2008). However, highly fermentable diets are rapidly converted to organic acids within the rumen and they readily dissociate to decrease $\mathrm{pH}$. This process can increase the risk of subacute and acute acidosis, inhibit fiber digestion by bacteria (Plaizier et al., 2001) and it is associated with perturbations of the plasma profiles (Ametaj et al., 2009).

Although there have been many studies on the effect of wheat (e.g., cracked, $\mathrm{NaOH}$ treatment, steam-rolled) on dairy cows performance (De Campeneere et al., 2006), there is little published information on the potential use of 
coarsely ground wheat $(\mathrm{CGW})$ as a primary ingredient in rations for lactating dairy cows. Therefore, the objective of the present experiment was to investigate the effect of a linear increase in the level of CGW as a substitute for ground corn (GC) in diets on ruminal fermentation characteristics, feed intake and digestion, lactation performance and plasma metabolites profiles in lactation Holstein cows.

\section{MATERIALS AND METHODS}

\section{Animals and experimental design}

Animal care and procedures were approved and conducted under established standards of the College of Animal Science and Technology, China Agricultural University. Eight healthy, multiparous, lactating Holstein cows (569 $\pm 47 \mathrm{~kg}$ of BW; $84 \pm 17$ DIM; mean \pm SD), four of which were fitted with ruminal cannulas (10 id; Bar Diamond, Parma, ID), were used in a replicated $4 \times 4$ Latin square design with 21 -d periods and four dietary treatments. The fistulated cows formed one replicate within each treatment to monitor ruminal fermentation.

The experiment was conducted at the experimental dairy farm of the State Key Laboratory of Animal Nutrition (Beijing, China). The cows were housed in individual tiestalls bedded with rubber mattresses and free access to drinking water throughout the trial.

\section{Diets and management}

The diets were fed as total mixed ration (TMR) (CAUmixer wagon model JZC-200, Beijing, China) and formulated with different levels of $\mathrm{CGW}$ and $\mathrm{GC}$; the ratio of concentrate to forage was kept constant and equal to 53:47 on DM basis. The four hard red winter wheat levels in the four TMRs were $0,9.6,19.2$, and $28.8 \% \mathrm{DM}$, and the four yellow dent corn levels were 27.9, 19.2, 9.6, and 0\% DM. The levels of replacement were chosen in this study, due to loose feces being observed in the high CGW diets (30\%, DM basis) in the original design (i.e., 45:55 forage to concentrate) when the first period experiment was conducted. Consequently, the concentrate feeding levels were reduced (i.e., 47:53 forage to concentrate) in all diets. The wheat and corn were ground in a multi-cavity hammer mill (Model No. Z6037; Shuangyi, Tangshan, China) and passed through $3.0-\mathrm{mm}$ and $3.5-\mathrm{mm}$ screens, respectively. Geometric mean particle sizes of the ground wheat and corn were $1,139 \mu \mathrm{m}$ and $666 \mu \mathrm{m}$, respectively (ASAE, 1983). The four diets (Table 1) were formulated to meet or exceed the NRC (2001) guidelines for $600 \mathrm{~kg}$ multiparous Holstein dairy cows producing $28 \mathrm{~kg}$ of milk/d with $4.0 \%$ fat. All diets were formulated to be isoenergetic and isonitrogenous, by adjusting the levels of soybean meal and ruminally inert fats. All ingredients were purchased and prepared once before the start of the experiment. The forage component of the diets was a mixture of corn silage, chopped alfalfa hay, and Chinese wild rye. Moisture content of the silage was determined weekly and used to make ration adjustments. During each data collection period, particle size distribution of TMR was determined using a Penn State Particle Separator (PSPS) as described by Lammers et al. (1996). Percentages (as-fed basis) of the TMR retained on the 19.0-, $8.0-$, and 1.18-mm screens, and the bottom pan of the PSPS were $32.5,19.6,29.0$, and $18.9 \%$, respectively, and numerically similar across diets.

Each experimental period consisted of a 14-d period of adaptation to the diets, followed by 7-d (d 15 to 21) for sample collection and other measurements. The first $3 \mathrm{~d}$ of each period were used to adjust the dairy cows gradually to their new diets. The cows were fed twice daily, in equal amounts, at 0700 and $1900 \mathrm{~h}$. The diets were fed ad libitum to allow for at least 5 to $10 \%$ orts on an as-fed basis.

\section{Sampling and analytical procedures}

Feed intake and digestibility: During the last 7 days of each period, diet and ort samples of individual cows were harvested daily to calculate feed intake. From d 18 to 20, fecal grab samples (300 to $500 \mathrm{~g}$ fresh basis) were collected on 12 occasions, at $0400,0900,1400,1900,0500,1000$, $1500,2000,0600,1100,1700$, and 2200 . The daily diets, orts, and fecal matter were pooled by dietary treatment, period, and cows, and stored at $-20^{\circ} \mathrm{C}$ until analysis. After the experiment, all samples were dried at $65^{\circ} \mathrm{C}$ in a forcedair oven (Model 2000; Experimental Mill, Beijing, China) for $48 \mathrm{~h}$ to a constant weight, ground through a $1-\mathrm{mm}$ screen using a Wiley mill (standard model 4; Arthur H. Thomas Co., Philadelphia, PA, USA), and analyzed for DM, ADF (method 973.18c; AOAC, 1990), and starch (Bal et al., 2000). The NDF was measured by the method of Van Soest et al. (1991) with heat-stable $\alpha$-amylase (A-3306; Sigma Chemical Co., St. Louis, MO, USA), and sodium sulfite and ash concentration was corrected for the Ankom 200 fiber analyzer (Ankom Technology, Fairport, NY, USA). The CP was determined by the micro-Kjeldahl method (method 4.2.08; AOAC, 1990). The ether extract (method 920.85; AOAC, 1990), calcium and phosphorus (method 945.46; AOAC, 1990) were also analyzed.

The acid-insoluble ash (AIA) was used as an intrinsic digestibility marker to estimate nutrient digestibility in the total tract. The AIA in the diets and feces were analyzed according to Van Keulen and Young (1977), using the equation described by Zhong et al. (2008) to calculate the apparent digestibility of a nutrient in the gastrointestinal tract. The equation is as follows: $\mathrm{D}=(1-(\mathrm{Ad} \times \mathrm{Nf}) /(\mathrm{Af} \times \mathrm{Nd}))$ $\times 100$, where $\mathrm{Ad}(\mathrm{g} / \mathrm{kg})$ and $\mathrm{Af}(\mathrm{g} / \mathrm{kg})$ represent the AIA in the diets and feces, respectively, and $\mathrm{Nd}(\mathrm{g} / \mathrm{kg})$ and $\mathrm{Nf}$ $(\mathrm{g} / \mathrm{kg})$ represent the nutrient in the diets and feces, 
Table1. Ingredient and nutrient composition of experimental diets

\begin{tabular}{|c|c|c|c|c|}
\hline \multirow{2}{*}{ Item } & \multicolumn{4}{|c|}{ Dietary treatment (\% CGW) } \\
\hline & 0 & 9.6 & 19.2 & 28.8 \\
\hline \multicolumn{5}{|l|}{ Ingredient/diets (\% of DM) } \\
\hline Corn silage & 27.0 & 27.0 & 27.0 & 27.0 \\
\hline Alfalfa hay & 14.0 & 14.0 & 14.0 & 14.0 \\
\hline Chinese wildrye & 6.0 & 6.0 & 6.0 & 6.0 \\
\hline Corn(ground) & 27.9 & 19.2 & 9.6 & 0 \\
\hline Wheat(coarsely ground) & 0 & 9.6 & 19.2 & 28.8 \\
\hline Soybean meal & 10.4 & 9.1 & 7.2 & 5.8 \\
\hline Cottonseed meal & 3.4 & 3.4 & 3.4 & 3.4 \\
\hline $\operatorname{DDGS}^{1}$ & 4.3 & 4.3 & 4.3 & 4.3 \\
\hline Wheat bran & 0 & 0.3 & 2.0 & 3.2 \\
\hline Whole cottonseed & 4.0 & 4.0 & 4.0 & 4.0 \\
\hline Ruminally inert fat ${ }^{2}$ & 0.1 & 0.3 & 0.5 & 0.7 \\
\hline Mineral-vitamin premix ${ }^{3}$ & 0.5 & 0.5 & 0.5 & 0.5 \\
\hline Dicalcium phosphate & 0.6 & 0.5 & 0.4 & 0.3 \\
\hline Limestone & 0.8 & 0.8 & 0.8 & 0.8 \\
\hline Sodium bicarbonate & 0.5 & 0.5 & 0.5 & 0.5 \\
\hline Magnesium oxide & 0.2 & 0.2 & 0.2 & 0.2 \\
\hline Salt & 0.4 & 0.4 & 0.4 & 0.4 \\
\hline \multicolumn{5}{|c|}{ Chemical composition (\% of DM) } \\
\hline $\mathrm{CP}$ & 15.9 & 16.1 & 16.2 & 16.4 \\
\hline $\mathrm{NE}_{\mathrm{L}}^{4}, \mathrm{Mcal} / \mathrm{kg}$ & 1.59 & 1.59 & 1.59 & 1.59 \\
\hline $\mathrm{NDF}$ & 35.2 & 35.8 & 36.8 & 37.4 \\
\hline $\mathrm{ADF}$ & 20.0 & 20.9 & 20.9 & 21.4 \\
\hline FNDF $^{5}$ & 30.2 & 30.2 & 30.2 & 30.2 \\
\hline Starch & 31.7 & 31.6 & 31.4 & 31.2 \\
\hline Ether extract & 3.4 & 3.4 & 3.4 & 3.4 \\
\hline $\mathrm{Ca}$ & 0.8 & 0.8 & 0.8 & 0.8 \\
\hline Total P & 0.4 & 0.4 & 0.4 & 0.4 \\
\hline
\end{tabular}

${ }^{1}$ Dried distillers grains with soluble. ${ }^{2}$ RumiFat (R100): Prilled hydrogenated palm FA distillate (Ecolex Sdn. Bhd, Malaysia).

${ }^{3}$ Contained (/kg of premix; DM basis):1,000,000 IU vitamin A; 65,000 IU vitamin D; 5,000 IU vitamin E; 2,000 mg Fe; 2,550 mg Mn; 5,500 mg Zn; 1,750 mg Cu; 70 mg I; 40 mg Co; 75 mg Se.

${ }^{4}$ Calculated using NE $\mathrm{L}$ values of feedstuffs from NRC (2001). ${ }^{5}$ Forage neutral detergent fiber.

respectively.

Ruminal parameters: Ruminal samples were collected for $\mathrm{pH}$, volatile fatty acids (VFA) and $\mathrm{NH}_{3}-\mathrm{N}$ analysis. Ruminal fluid $(100 \mathrm{ml}$ ) was sampled at 0700 (before the meal), 1000, 1300, 1600 and $1900 \mathrm{~h}$ on d 16 and 17, collected manually from the anterior dorsal, anterior ventral, medial ventral, posterior dorsal, and posterior ventral locations within the rumen, composited by cows. Samples were filtered through four layers of cheesecloth. At each sampling time, the $\mathrm{pH}$ was measured immediately after collection using a hand-held $\mathrm{pH}$ electrode (Model pH B-4; Shanghai Chemical, Shanghai, China). The $\mathrm{NH}_{3}-\mathrm{N}$ concentration of ruminal samples was determined using a phenol-hypochlorite assay (Broderick and Kang, 1980). For VFA analysis, a 20-ml filtered sample was put into a plastic bottle with $3 \mathrm{ml}$ of $25 \%$ metaphosphoric acid and $3 \mathrm{ml}$ of $0.6 \%$ 2-ethyl butyric acid (internal standard), and stored at $-20^{\circ} \mathrm{C}$. The VFA concentration and profile were determined as described by Cao et al. (2008), using gas chromatography (7980; Agilent Technologies Inc, Santa Clara, CA) equipped with a 30 m HP-INNOWax 19091N213 (Agilent) capillary column $(0.32 \mathrm{~mm}$ id and $0.50 \mathrm{~mm}$ film thickness).

Milk yield and milk composition: The cows were milked twice daily, at 0630 and $1830 \mathrm{~h}$. Milk weights were recorded during the 7-d data collection period, and milk samples were taken from d18 to 20 of each experimental period. Milk samples (protein, fat, lactose, and solids nonfat content (SNF)) were analyzed by the Beijing Dairy Cattle Center with a near-infrared reflectance spectroscopy analyzer (MilkoScan 605; Foss Electric, Hillerød, Denmark). Milk production was converted to $3.5 \%$ fatcorrected milk (FCM) yield as $(0.434 \times \mathrm{kg}$ of milk) $+(16.216 \times \mathrm{kg}$ of milk fat). The energy corrected milk (ECM) yield was calculated with the equation $\mathrm{ECM}=0.327 \times$ milk $(\mathrm{kg})+12.95 \times$ fat $(\mathrm{kg})+7.20 \times$ protein $(\mathrm{kg})$, on the basis of 
individual cows (Tyrrell and Reid, 1965).

Plasma metabolite profiles: On d 21 of each experimental period, $10 \mathrm{ml}$ of blood samples were collected, via tail venipuncture at $6 \mathrm{~h}$ after the morning feeding, into vacutainer tubes (Becton Dickinson, Franklin Lakes, NJ, USA) containing sodium heparin anticoagulant. Plasma was collected after centrifugation at $3,000 \times \mathrm{g}$ for $10 \mathrm{~min}$, separated into several aliquots, frozen at $-20^{\circ} \mathrm{C}$, and later analyzed for determination of glucose, insulin, nonesterified fatty acid (NEFA), BHBA, triglycerides, cholesterol and urea nitrogen. All plasma-related measurements were analyzed in duplicate. The levels of glucose, triglycerides, cholesterol and urea in plasma were analyzed using a clinical auto-analyzer (Cobas Integra, C701; Hoffmann-La Roche Ltd, Basel, Switzerland). The glucose and urea nitrogen (PUN) concentrations were determined using the GOD/PAP and Urease-GLDH test kit (Merit Choice Bioengineering Co., Ltd, Beijing, China). The triglycerides and total cholesterol concentrations were determined following the kit instructions (Shensuo Unf Medical Diagnostic Article Co., Ltd, Shanghai, China), using the enzymatic method. The NEFA and BHBA concentrations in plasma were analyzed with a Hitachi 7600 automated biochemistry analyzer (Hitachi Co., Tokyo, Japan). The NEFA concentrations were determined using a commercially available kit (Sekisui Medical Co., Ltd, Tokyo, Japan). BHBA dehydrogenase was used for quantifying the plasma concentration of BHBA using a commercially available kit (Jingyuan Medical Co., Ltd, Shanghai, China). The plasma insulin levels were determined using an insulin radioimmunoassay kit (Beijing North Institute of Biological Technology, Beijing, China) with a radioimmunoassay system (xh6080; Xi'an Nuclear Instrument Factory, Xi'an, China) according to the manufacturer's instructions.

\section{Statistical analysis}

Data on DMI, digestibility, lactation performance and plasma metabolite profile were analyzed statistically according to a replicated Latin square design using the GLM procedure of the SAS Institute (2002), using the following model: $\mathrm{Y}_{\mathrm{ijkl}}=\mu+\mathrm{P}_{\mathrm{i}}+\mathrm{C}_{\mathrm{j}(\mathrm{l})}+\mathrm{T}_{\mathrm{k}}+\mathrm{S}_{\mathrm{l}}+\mathrm{ST}_{\mathrm{lk}}+\mathrm{E}_{\mathrm{ijkl}}$, where $\mathrm{Y}_{\mathrm{ijkl}}=$ dependent variable; $\mu=$ overall mean; $\mathrm{P}_{\mathrm{i}}=$ effect of period $\mathrm{i} ; \mathrm{C}_{\mathrm{j}(\mathrm{l})}=$ effect of cow $\mathrm{j}$ within square $1 ; \mathrm{T}_{\mathrm{k}}=$ effect of treatment $\mathrm{k} ; \mathrm{S}_{\mathrm{l}}=$ square effect $(1=1$ or 2$) ; \mathrm{ST}_{\mathrm{lk}}=$ interaction between square 1 and treatment $\mathrm{k}$; and $\mathrm{E}_{\mathrm{ijkl}}=$ the random residual error.

Rumen fermentation data, which had repeated measures over time, was analyzed using the following model: $\mathrm{Y}_{\mathrm{ijkm}}=$ $\mu+\mathrm{P}_{\mathrm{i}}+\mathrm{C}_{\mathrm{j}}+\mathrm{T}_{\mathrm{k}}+\mathrm{H}_{\mathrm{m}}+\mathrm{HT}_{\mathrm{mk}}+\mathrm{E}_{\mathrm{ijkm}}$, where $\mathrm{Y}_{\mathrm{ijkm}}=$ dependent variable; $\mu=$ overall mean; $P_{i}=$ effect of period $i ; C_{j}=$ effect of cow j; $\mathrm{T}_{\mathrm{k}}=$ effect of treatment $\mathrm{k} ; \mathrm{H}_{\mathrm{m}}=$ effect of hours post-feeding analyzed as repeated measures; $\mathrm{HT}_{\mathrm{mk}}=$ interaction between hour $\mathrm{m}$ and treatment $\mathrm{k}$; and $\mathrm{E}_{\mathrm{ijkm}}=$ random residual error.

The above data were compared by Tukey's range test. Orthogonal polynomial contrasts were used to examine the responses (linear and quadratic) to increasing the substitution level of $\mathrm{CGW}$ for GC in the diets. In orthogonal polynomial analysis, coefficients were corrected due to unequal spacing of treatment.

\section{RESULTS}

\section{DM intake and total tract nutrient digestibility}

In the current study, DM intake (DMI) was not significantly affected by the levels of CGW in the diet; however, increasing levels of CGW resulted in a quadratic pattern $(\mathrm{p}=0.07)$ in daily DMI, which was maximized when cows were fed the 9.6 and $19.2 \%$ CGW diets, and then declined when $\mathrm{CGW}$ was included at $28.8 \%$ of diet DM (Table 4). Apparent digestibility of CP was not altered in response to CGW feeding (Table 2); however, linear decreases were observed in apparent DM $(\mathrm{p}=0.02)$, NDF $(\mathrm{p}<0.01)$, and ADF $(\mathrm{p}<0.01)$ digestibility with increasing levels of CGW in the diet. Moreover, digestibility of NDF and ADF decreased significantly $(\mathrm{p}<0.01)$ in cows fed $28.8 \%$ CGW diets. Apparent digestibility of starch responded quadratically $(\mathrm{p}=0.03)$ to the replacement of GC with CGW.

\section{Ruminal parameters}

Ruminal $\mathrm{pH}$ remained in the normal physiological range for all dietary treatments at all times, except for the $28.8 \%$ $\mathrm{CGW}$ diets at $6 \mathrm{~h}$ after feeding (Figure 1); moreover, with

Table 2. Effect of replacing dietary GC with CGW on total tract nutrient digestibility in dairy cows (\%)

\begin{tabular}{|c|c|c|c|c|c|c|c|}
\hline \multirow{2}{*}{ Item } & \multicolumn{4}{|c|}{ Dietary treatment (\% CGW) } & \multirow{2}{*}{$\mathrm{SEM}^{1}$} & \multicolumn{2}{|c|}{$\mathrm{p}$ value } \\
\hline & 0 & 9.6 & 19.2 & 28.8 & & Linear & Quadratic \\
\hline$\overline{\mathrm{DM}}$ & 68.8 & 67.8 & 67.1 & 66.3 & 0.56 & 0.02 & 0.54 \\
\hline NDF & $53.5^{\mathrm{a}}$ & $52.7^{\mathrm{a}}$ & $49.1^{\mathrm{ab}}$ & $46.4^{\mathrm{b}}$ & 0.86 & $<0.01$ & 0.85 \\
\hline $\mathrm{ADF}$ & $52.4^{\mathrm{a}}$ & $52.3^{\mathrm{a}}$ & $48.8^{\mathrm{ab}}$ & $45.6^{\mathrm{b}}$ & 0.79 & $<0.01$ & 0.77 \\
\hline $\mathrm{CP}$ & 71.4 & 71.4 & 71.2 & 71.0 & 0.50 & 0.69 & 0.95 \\
\hline Starch & 88.4 & 87.6 & 86.3 & 87.8 & 0.53 & 0.47 & 0.03 \\
\hline
\end{tabular}

${ }^{\mathrm{a}-\mathrm{b}}$ Means with different superscripts in the same row differ (Tukey's test; $\mathrm{p}<0.05$ ). ${ }^{1} \mathrm{SEM}=\mathrm{Standard}$ error of the mean. 


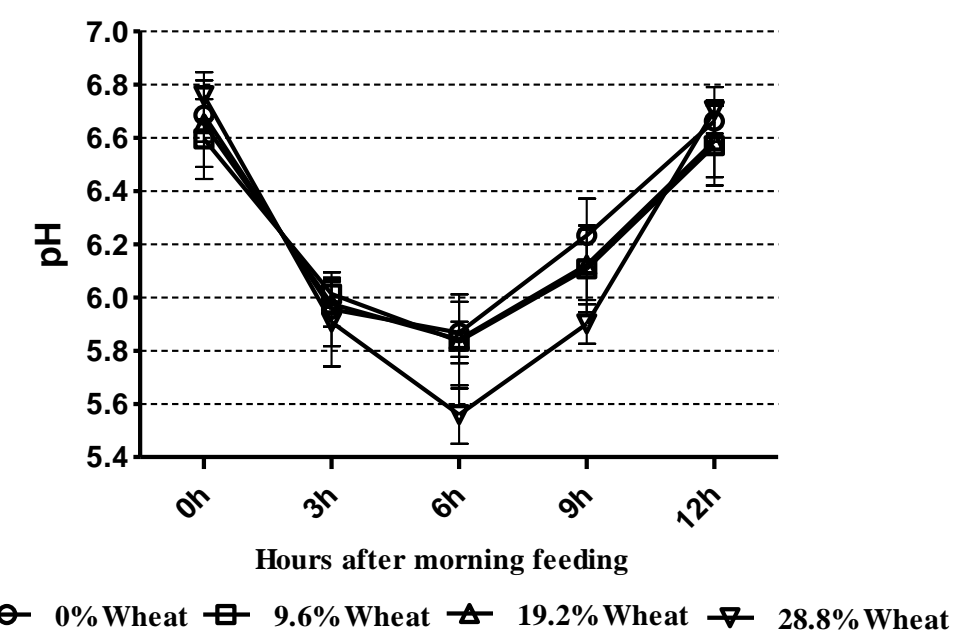

Figure 1. Diurnal patterns of rumen $\mathrm{pH}$ as influenced by dietary treatments. Error bar is SEM.

increasing levels of CGW in the diet, the daily mean ruminal $\mathrm{pH}$ decreased linearly $(\mathrm{p}=0.01)$ (Table 3$)$. Concentrations of ruminal $\mathrm{NH}_{3}-\mathrm{N}$ tended to increase linearly $(\mathrm{p}=0.06)$ with increasing levels of dietary CGW. Neither concentration nor percentage of acetate, butyrate, valerate, isobutyrate and isovalerate were affected by the diets; however, ruminal propionate concentration increased linearly $(p<0.01)$ when the level of dietary CGW was increased, while the acetate to propionate ratio decreased linearly $(\mathrm{p}=0.03)$ when $\mathrm{CGW}$ was included at $28.8 \%$ of diet DM. The percentage of propionate increased linearly $(\mathrm{p}<0.01)$ in cows fed the $28.8 \% \mathrm{CGW}$ diets. Total VFA concentration increased quadratically $(\mathrm{p}=$ 0.04) with increasing levels of dietary CGW.

\section{Milk yield and milk composition}

Milk yield was not affected by diet, and it averaged 27.1 $\mathrm{kg} / \mathrm{d}$; however, milk yield was numerically lower for the 28.8\% CGW diets (Table 4). The percentage and yield of milk protein, lactose, and SNF were not different across diets; however, increasing levels of dietary CGW resulted in a linear decrease in milk fat percentage $(p=0.02)$, with a tendency for a linear decrease in milk fat yield $(\mathrm{p}=0.02)$, $3.5 \%$ FCM yield $(p=0.05)$, and ECM yield $(p=0.06)$. Feed efficiency expressed as milk/kg of DMI was not affected by diet; however, 3.5\% FCM/DMI decreased linearly $(p=0.04)$ and quadratically $(p=0.01)$ when the level of CGW was increased. Nitrogen efficiency was not affected by diet.

Table 3. Effect of replacing dietary GC with CGW on $\mathrm{pH}$ and concentration of metabolites in the rumen ${ }^{1}$

\begin{tabular}{|c|c|c|c|c|c|c|c|}
\hline \multirow{2}{*}{ Item } & \multicolumn{4}{|c|}{ Dietary treatment (\% CGW) } & \multirow{2}{*}{$\mathrm{SEM}^{2}$} & \multicolumn{2}{|c|}{$\mathrm{p}$ value } \\
\hline & 0 & 9.6 & 19.2 & 28.8 & & Linear & Quadratic \\
\hline$\overline{\text { Ruminal } \mathrm{pH}}$ & 6.28 & 6.22 & 6.23 & 6.16 & 0.05 & 0.01 & 0.98 \\
\hline Ruminal $\mathrm{NH}_{3}-\mathrm{N}(\mathrm{mg} / 100 \mathrm{ml})$ & 11.97 & 12.02 & 12.36 & 13.08 & 0.49 & 0.06 & 0.66 \\
\hline \multicolumn{8}{|l|}{ VFA concentration $(\mathrm{mmol} / \mathrm{L})$} \\
\hline Acetate & 64.82 & 66.79 & 67.05 & 63.45 & 1.44 & 0.18 & 0.15 \\
\hline Propionate & $22.94^{\mathrm{b}}$ & $23.30^{\mathrm{b}}$ & $23.65^{\mathrm{ab}}$ & $25.29^{\mathrm{a}}$ & 0.87 & $<0.01$ & 0.32 \\
\hline Butyrate & 8.52 & 9.03 & 9.31 & 8.07 & 0.29 & 0.47 & 0.18 \\
\hline Isobutyrate & 0.83 & 0.85 & 0.87 & 0.77 & 0.02 & 0.42 & 0.36 \\
\hline Valerate & 1.23 & 1.33 & 1.44 & 1.36 & 0.05 & 0.31 & 0.22 \\
\hline Isovalerate & 1.26 & 1.33 & 1.20 & 1.07 & 0.06 & 0.09 & 0.50 \\
\hline Total VFA & 99.61 & 102.64 & 103.51 & 98.89 & 2.14 & 0.51 & 0.04 \\
\hline \multicolumn{8}{|l|}{ VFA ( mmol/100 mmol total) } \\
\hline Acetate & 65.19 & 65.16 & 64.85 & 64.30 & 0.58 & 0.56 & 0.91 \\
\hline Propionate & $22.87^{\mathrm{b}}$ & $22.54^{\mathrm{b}}$ & $22.69^{b}$ & $25.39^{\mathrm{a}}$ & 0.74 & $<0.01$ & 0.03 \\
\hline Butyrate & 8.61 & 8.86 & 9.06 & 8.20 & 0.32 & 0.60 & 0.41 \\
\hline Acetate:propionate ratio & 2.95 & 3.00 & 2.97 & 2.68 & 0.10 & 0.03 & 0.14 \\
\hline
\end{tabular}

\footnotetext{
${ }^{\mathrm{a}-\mathrm{b}}$ Means with different superscripts in the same row differ (Tukey's test; $\mathrm{p}<0.05$ ).
}

${ }^{1}$ Values are means across sampling times of $0,3,6,9$, and $12 \mathrm{~h}$ after morning feeding. ${ }^{2} \mathrm{SEM}=$ Standard error of the mean. 
Table 4. Effect of replacing dietary GC with CGW on DMI, milk yield and compositions in dairy cows

\begin{tabular}{|c|c|c|c|c|c|c|c|}
\hline \multirow{2}{*}{ Item } & \multicolumn{4}{|c|}{ Dietary treatment (\% CGW) } & \multirow{2}{*}{ SEM $^{1}$} & \multicolumn{2}{|c|}{$\mathrm{p}$ value } \\
\hline & 0 & 9.6 & 19.2 & 28.8 & & Linear & Quadratic \\
\hline$\overline{\mathrm{DMI}}(\mathrm{kg} / \mathrm{d})$ & 19.14 & 20.09 & 20.02 & 19.73 & 0.19 & 0.40 & 0.07 \\
\hline $\operatorname{Milk}(\mathrm{kg} / \mathrm{d})$ & 27.16 & 27.05 & 27.10 & 26.45 & 0.49 & 0.28 & 0.66 \\
\hline $3.5 \%$ FCM $(\mathrm{kg} / \mathrm{d})$ & 27.72 & 27.68 & 27.75 & 26.45 & 0.49 & 0.05 & 0.27 \\
\hline $\operatorname{ECM}(\mathrm{kg} / \mathrm{d})^{2}$ & 28.15 & 28.06 & 28.26 & 26.98 & 0.46 & 0.06 & 0.24 \\
\hline Milk fat (\%) & 3.64 & 3.65 & 3.65 & 3.50 & 0.05 & 0.02 & 0.15 \\
\hline Milk protein $(\%)$ & 3.34 & 3.31 & 3.36 & 3.33 & 0.03 & 0.98 & 0.81 \\
\hline Milk lactose (\%) & 5.04 & 5.07 & 4.99 & 5.04 & 0.03 & 0.84 & 0.57 \\
\hline SNF (\%) & 9.09 & 9.09 & 9.13 & 9.10 & 0.04 & 0.77 & 0.69 \\
\hline Milk fat (kg/d) & 0.99 & 0.99 & 0.99 & 0.93 & 0.02 & 0.02 & 0.94 \\
\hline Milk protein (kg/d) & 0.90 & 0.89 & 0.91 & 0.88 & 0.01 & 0.30 & 0.29 \\
\hline Milk lactose (kg/d) & 1.37 & 1.38 & 1.35 & 1.34 & 0.03 & 0.34 & 0.50 \\
\hline $\mathrm{SNF}(\mathrm{kg} / \mathrm{d})$ & 2.46 & 2.46 & 2.48 & 2.41 & 0.04 & 0.36 & 0.53 \\
\hline Milk/DMI & 1.43 & 1.35 & 1.35 & 1.34 & 0.03 & 0.15 & 0.66 \\
\hline $3.5 \% \mathrm{FCM} / \mathrm{DMI}$ & 1.45 & 1.38 & 1.39 & 1.34 & 0.03 & 0.04 & 0.01 \\
\hline Nitrogen efficiency $(g / g)^{3}$ & 0.27 & 0.26 & 0.26 & 0.26 & 0.01 & 0.15 & 0.57 \\
\hline
\end{tabular}

${ }^{a-b}$ Means with different superscripts in the same row differ (Tukey's test; $\mathrm{p}<0.05$ ).

${ }^{1} \mathrm{SEM}=$ Standard error of the mean.

${ }^{2}$ Energy corrected milk $=(0.327 \times$ milk production $(\mathrm{kg} / \mathrm{d}))+(12.95 \times$ fat yield $(\mathrm{kg} / \mathrm{d}))+(7.2 \times$ protein yield $(\mathrm{kg} / \mathrm{d}))$

${ }^{3}$ Nitrogen efficiency $(\mathrm{g} \mathrm{N} / \mathrm{g} \mathrm{N})=($ milk protein yield $(\mathrm{kg} / \mathrm{d}) / 6: 38) /($ crude protein intake $(\mathrm{kg} / \mathrm{d}) / 6: 25)$.

\section{Plasma metabolite profiles}

The concentrations of plasma BHBA $(\mathrm{p}=0.07)$ tended to decrease linearly, whereas plasma glucose $(p=0.08)$, insulin $(\mathrm{p}=0.02)$ and urea nitrogen $(\mathrm{p}=0.02)$ tended to increase linearly, with increasing dietary CGW levels; plasma NEFA was not affected by diet (Table 5). Plasma cholesterol concentrations decreased linearly $(\mathrm{p}<0.01)$ with increasing dietary CGW levels, and decreased significantly $(\mathrm{p}<0.01)$ in cows fed the $28.8 \%$ CGW diets. Plasma triglyceride concentration tended to respond quadratically $(p=0.08)$ to the replacement of GC with CGW.

\section{DISCUSSION}

\section{DM intake and total tract nutrient digestibility}

Wheat has generally been considered a risk to reduce feed intake for its higher ruminally available starch (NRC, 2001); however, DMI was not significantly affected by replacing GC with CGW in the current study. Recent research indicates that dairy cows fed 20\% dietary DM steam-rolled wheat, in place of steam-rolled barley, had similar feed intakes (Doepel et al., 2009). Faldet et al. (1989) also showed that the concentrate mixtures with $60 \%$ wheat had no influence on the DMI of dairy cows. In contrast, increasing levels of wheat in the diets decreased DMI in other studies (Gozho and Mutsvangwa, 2008; Lechartier and Peyraud, 2010). In the current study, DMI tended to increase quadratically with increasing levels of dietary CGW; this may be a reflection of the CGW having higher palatability than GC for dairy cows. Nikkhah et al. (2010) indicated that $18 \%$ dietary DM ground wheat could feasibly be fed to periparturient cows to improve DMI and energy balances.

In the present study, apparent digestibility of DM, NDF, and ADF were reduced in cows fed the $28.8 \%$ CGW diets. This result may reflect the negative associated effects of

Table 5. Effect of replacing dietary GC with CGW on plasma metabolites profiles in dairy cows ${ }^{1}$

\begin{tabular}{|c|c|c|c|c|c|c|c|}
\hline \multirow{2}{*}{ Item } & \multicolumn{4}{|c|}{ Dietary treatment (\% CGW) } & \multirow{2}{*}{$\mathrm{SEM}^{2}$} & \multicolumn{2}{|c|}{$\mathrm{p}$ value } \\
\hline & 0 & 9.6 & 19.2 & 28.8 & & Linear & Quadratic \\
\hline BHBA (mmol/L) & 0.85 & 0.88 & 0.77 & 0.72 & 0.04 & 0.07 & 0.84 \\
\hline Cholesterol (mmol/L) & $3.25^{\mathrm{a}}$ & $3.20^{\mathrm{a}}$ & $3.14^{\mathrm{a}}$ & $2.68^{\mathrm{b}}$ & 0.08 & $<0.01$ & 0.22 \\
\hline $\operatorname{NEFA}(\mu \mathrm{Eq} / \mathrm{L})$ & 108.13 & 107.25 & 114.75 & 110.00 & 2.91 & 0.69 & 0.56 \\
\hline Glucose (mmol/L) & 2.91 & 3.04 & 3.05 & 3.21 & 0.08 & 0.08 & 0.97 \\
\hline Insulin $(\mu \mathrm{IU} / \mathrm{ml})$ & 7.09 & 7.40 & 8.02 & 9.76 & 0.45 & 0.02 & 0.65 \\
\hline PUN (mmol/L) & 5.21 & 5.40 & 5.48 & 5.81 & 0.09 & 0.02 & 0.94 \\
\hline Triglyceride (mmol/L) & 0.17 & 0.18 & 0.18 & 0.17 & 0.01 & 0.60 & 0.08 \\
\hline
\end{tabular}

\footnotetext{
${ }^{a-b}$ Means with different superscripts in the same row differ (Tukey's test; $p<0.05$ ).
}

${ }^{1}$ Blood samples were taken $6 \mathrm{~h}$ post morning feeding. ${ }^{2} \mathrm{SEM}=$ Standard error of the mean. 
fermentable carbohydrates and fiber degradability in the rumen (Firkins, 1997). Ruminal pH decreased to 5.56 at $6 \mathrm{~h}$ after feeding when cows were fed the $28.8 \% \mathrm{CGW}$ diets in this trial (Figure 1), resulting in the lower digestibility of the NDF (Leddin et al., 2009). An in vitro study by Stensig et al. (1998) showed that with a higher proportion of wheat starch in the diet, the rate of digestion and passage of NDF decreased. However, Gozho and Mutsvangwa (2008) did not observe that total tract digestibility of DM, OM, and NDF were affected by the dietary source of carbohydrate, but total tract ADF digestibility tended to be lower in cows fed the wheat-based (32.8\%, DM basis) TMR compared with those fed the corn-based (28.7\%, DM basis) TMR. Martin et al. (1999) reported that ruminal NDF digestibility and most fibrolytic activities of the solid-associated microorganisms were lower in beef steers fed wheat-based diets than in those fed corn-based diets. In dairy cows, the main site of cereal grain starch digestion is the rumen, and wheat exhibits faster and more extensive ruminal starch degradation compared with the corn (Huntington, 1997). It was expected that total tract starch digestibility would be greater in cows fed the CGW. However, in this trial, the lower digestibility of starch occurred in the 19.2\% CGW diets. This was unexpected and is difficult to explain. Apparent total tract digestibility of $\mathrm{CP}$ was not different among the treatments, and is in agreement with other studies (Doepel et al., 2009; Gozho and Mutsvangwa, 2008).

\section{Ruminal parameters}

In our study, ruminal $\mathrm{pH}$ remained in the normal physiological range for all dietary treatments, except for the $28.8 \% \mathrm{CGW}$ diets at $6 \mathrm{~h}$ after feeding. Lower ruminal $\mathrm{pH}$ might increase the risk of subacute ruminal acidosis (SARA). It is recognized that SARA occurs in repeated periods of lowered $\mathrm{pH}$, below 5.6 to 5.8 (Lechartier and Peyraud, 2011). Our results are similar to findings from the study conducted by Doepel et al. (2009), who determined that 10 or $20 \%$ of dietary DM steam-rolled wheat led to lower ruminal $\mathrm{pH}$, but all dietary treatments remained in the normal physiological range. Moreover, Lechartier and Peyraud (2011) showed that increasing wheat (14.6 and $29.7 \%$, DM basis) in the diets increased ruminal $\mathrm{pH}$ range and linearly decreased ruminal fibrolytic activity, estimated from the disappearance of soybean hull DM after $24 \mathrm{~h}$ of in sacco incubation. An in vitro experiment showed that the acid-producing potential of wheat was higher than that of corn (acidogenicity values, 17.2 vs 12.6, respectively), and high levels of wheat inclusion in the diets increased ruminal lactic acid concentration in accordance with decreased rumen $\mathrm{pH}$ (Wadhwa et al., 2001). In contrast, Gozho and Mutsvangwa (2008) have reported similar ruminal $\mathrm{pH}$ levels in cows fed corn or wheat based TMR, which is difficult to explain biologically.
As described above, ruminal $\mathrm{NH}_{3}-\mathrm{N}$ concentration tended to increase linearly with increasing levels of dietary CGW. The increase in ruminal $\mathrm{NH}_{3}-\mathrm{N}$, possibly resulting from a reduction in microbial capture of released $\mathrm{NH}_{3}$ (Kolver et al., 1998), suggests that nitrogen efficiency is lower. This is also reflected in the linear increase in PUN. In contrast, Gozho and Mutsvangwa (2008) reported that ruminal $\mathrm{NH}_{3}-\mathrm{N}$ concentration was unaffected by dietary treatment (wheat or corn).

In the present research, ruminal propionate concentration increased linearly as the levels of dietary CGW increased, which is similar to the results of previous studies (Doepel et al., 2009; Lechartier and Peyraud, 2011). The variations in propionate concentrations and acetate to propionate ratio indicates a shift in ruminal fermentation pattern consistent with starch fermentability of the diets, and in accordance with the tendency toward a decrease in milk fat percentage or yield in our study. An in vitro study conducted by Russell (1998) showed that propionate production increased due to the ability of starch-degrading bacteria, which prefer to produce propionate. Increased total VFA concentration is an indication for either a higher rate of VFA production or a slower rate of VFA disappearance as levels of $\mathrm{CGW}$ increased in the diets. In general, the $\mathrm{pH}$ decreases with increasing ruminal VFA concentration after feeding (Dijkstra et al., 2012). However, cows that were fed the $28.8 \%$ CGW diets had lower ruminal $\mathrm{pH}$ values and total VFA concentration than other diets in this trial, which seems to be contradictory. Allen (1997) concluded that the relationship between ruminal VFA concentration and ruminal $\mathrm{pH}$ appears to be weak; the reason being related to large variations among diets in the removal, buffering, and neutralization of acids in the rumen. Furthermore, our results may be linked to the cows own regulation of microbial adaptation and VFA absorption (Krause and Oetzel, 2006), when fed diets containing high amounts of rapidly fermentable carbohydrates.

\section{Milk yield and milk composition}

In our study, milk yield was similar across dietary treatments, but numerically lower for the $28.8 \%$ CGW diet. In agreement with our findings, Doepel et al. (2009) observed no effect of $20 \%$ dietary DM steam-rolled wheat on milk yield of dairy cows. Gozho and Mutsvangwa (2008) reported that milk yield was being negatively affected by high levels of wheat which was probably caused by the diurnal pattern of ruminal $\mathrm{pH}$. Cows fed the $0,9.6$, and $19.2 \% \mathrm{CGW}$ diets had numerically greater milk $3.5 \%$ FCM and ECM yield values compared with those fed the $28.8 \%$ CGW diets, which could be due to the variation of milk yield and milk fat percentage in our study.

Milk fat percentage and yield decreased in cows fed the $28.8 \%$ CGW diets, indicating that feeding large amounts of 
CGW to dairy cows can negatively affect milk fat concentration, a result similar to that of previous research studies (Gozho and Mutsvangwa, 2008; Lechartier and Peyraud, 2011). This result could be attributed to the increased ruminal propionate production in our study, which may limit the flux of milk fat precursors towards the mammary gland (Doreau et al., 1999). Moreover, too much rapidly fermented starch had a significant impact on ruminal $\mathrm{pH}$, biohydrogenation, and bacterial community composition, which is associated with milk fat depression (Weimer et al., 2010).

Feed efficiency decreased linearly with the increase in dietary CGW levels, indicating that a large amount of CGW could depress energy utilization efficiency. This result might be caused by the higher levels of rapidly fermented starch tending to exaggerate diurnal patterns of ruminal $\mathrm{pH}$ and resulting in alterations of ruminal functions (Zebeli et al., 2011).

\section{Plasma metabolite profiles}

The observations obtained in the present study showed that plasma BHBA and cholesterol concentration were lower in the high proportion of CGW diets. Our results are similar to those previously reported by Ametaj et al. (2009). They demonstrated that feeding increasing proportions of barley grain was associated with lower concentrations of plasma BHBA and cholesterol in cows. Plasma BHBA comes from oxidation of NEFA in liver hepatocytes (Roche et al., 2008) or the butyrate (Andersson and Lundstroem, 1985), and lower plasma BHBA concentration is probably due to the variation in its sources. The lower cholesterol is related to changes in plasma amino acids, severity of acute phase response, and metabolic disorder, as reported by Chiarla et al. (2004). Zebeli et al. (2011) demonstrated inverse relationships between rumen endotoxin and plasma cholesterol or BHBA concentrations, which are related to the systemic inflammatory response triggered by translocation of an endotoxin into the peripheral circulation (Khafipour et al., 2009).

Plasma glucose concentrations tended to increase with increasing levels of CGW in the diets. This result might be related to a greater availability of starch from CGW, which provided more glucogenic precursors (propionate) than starch from GC. Van Knegsel et al. (2007) indicated that feeding diets containing large amounts of fermentable carbohydrates is associated with greater plasma glucose concentrations. Propionate and, to a lesser extent, glucose, are insulin secretagogues, and insulin is reported to inhibit hepatic gluconeogenesis (Brockman, 1985). Plasma insulin increased in cows fed high CGW diets in the present research, which indicates an increase in propionate production. The higher plasma glucose and insulin concentrations are also associated with the lower milk fat percentage in this trial. These findings might at least partly account for milk-fat depression, even though the glucogenic theory is still in doubt (Bergen, 2009).

Concentrations of PUN increased in cows fed high CGW diet, which indicates that a great amount of $\mathrm{NH}_{3}$ was released in the rumen after feeding, exceeding the capacity of microbes to utilize it. It is more likely that less $\mathrm{NH}_{3}$ was incorporated into microbial protein due to lower NDF digestion in this study. This led to a large portion of $\mathrm{NH}_{3}$ being absorbed across the rumen wall for urea synthesis in the liver, as well as its subsequent increased concentration in systemic circulation (Burgos et al., 2007). In the present research, plasma triglyceride concentration tended to increase quadratically as dietary CGW level increased in diets, a finding in agreement with the observations of Bradford and Allen (2004), who indicated that feeding easily degradable starch diets increased plasma triglyceride concentrations. The lower plasma triglyceride in cows fed the $28.8 \%$ CGW diet was probably due to decreased lipolysis and ruminal biohydrogenation at low rumen $\mathrm{pH}$ (Jenkins, 1993), thereby reducing triglyceride concentrations in peripheral blood circulation.

\section{CONCLUSIONS}

Our study revealed that $\mathrm{CGW}$ is a suitable substitute for GC in diets of lactating dairy cows when fed up to $19.2 \%$ of dietary DM. A practical concern with feeding CGW above $19.2 \%$ of dietary DM is that it could negatively affect nutrient digestibility, ruminal $\mathrm{pH}$, and milk fat concentration, and potentially alter the plasma metabolites.

\section{ACKNOWLEDGEMENT}

The study was supported by the funds from the National Key Basic Research Program of China (Project No. 2011CB100801) and National Science Foundation of China (30901030).

\section{REFERENCES}

Allen, M. S. 1997. Relationship between fermentation acid production in the rumen and the requirement for physically effective fiber. J. Dairy Sci. 80:1447-1462.

Ametaj, B. N., D. G. Emmanuel, Q. Zebeli, and S. M. Dunn. 2009. Feeding high proportions of barley grain in a total mixed ration perturbs diurnal patterns of plasma metabolites in lactating dairy cows. J. Dairy Sci. 92:1084-1091.

Andersson, L., and K. Lundstroem. 1985. Effect of feeding silage with high butyric acid content on ketone body formation and milk yield in postparturient dairy cows. Zentralbl. Veterinaermed. A 32:15-23.

AOAC. 1990. Official methods of analysis. 15th ed. Association of Official Analytical Chemists, Washington, DC. 
ASAE. 1983. Method of determining and expressing fineness of feed materials by sieving. Page 325 in ASAE Standard S319, Agriculture Engineers Yearbook of Standards. Am. Soc. Agric. Eng., St. Joseph, MI.

Bal, M. A., R. D. Shaver, A. G. Jirovec, K. J. Shinners, and J. G. Coors. 2000. Crop processing and chop length of corn silage: Effects on intake, digestion, and milk production by dairy cows. J. Dairy Sci. 83:1264-1273.

Bergen, W. G. 2009. Milk-fat depression and lipid repartitioning in lactating dairy cows. J. Nutr. 139:826-827.

Bradford, B. J., and M. S. Allen. 2004. Milk fat responses to a change in diet fermentability vary by production level in dairy cattle. J. Dairy Sci. 87:3800-3807.

Brockman, R. P. 1985. Role of insulin in regulating hepatic gluconeogenesis in sheep. Can. J. Physiol. Pharmacol. 63:1460-1464.

Broderick, G. A., and J. H. Kang. 1980. Automated simultaneous determination of ammonia and total amino acids in ruminal fluid and in vitro media. J. Dairy Sci. 63:64-75.

Burgos, S. A., J. G. Fadel, and E. J. DePeters. 2007. Prediction of ammonia emission from dairy cattle manure based on milk urea nitrogen: Relation of milk urea nitrogen to urine urea nitrogen excretion. J. Dairy Sci. 90:5499-5508.

Cao, Z. J., S. L. Li, J. J. Xing, M. Ma, and L. L. Wang. 2008. Effects of maize grain and lucerne particle size on ruminal fermentation, digestibility and performance of cows in midlactation. J. Anim. Physiol. Anim. Nutr. 92:157-167.

Chiarla, C. and I. Giovannini, and J. H. Siegel. 2004. The relationship between plasma cholesterol, amino acids and acute phase proteins in sepsis. Amino Acids 27:97-100.

De Campeneere, S., J. L. De Boever and D. L. De Brabander. 2006. Comparison of rolled, $\mathrm{NaOH}$ treated and ensiled wheat grain in dairy cattle diets. Livest. Sci. 99:267-276.

Dijkstra, J., J. L. Ellis, E. Kebreab, A. B. Strathe, S. López, J. France, and A. Bannink. 2012. Ruminal pH regulation and nutritional consequences of low pH. Anim. Feed Sci. Technol. 172:22-33.

Doepel, L., A. Cox, and A. Hayirli. 2009. Effects of increasing amounts of dietary wheat on performance and ruminal fermentation of Holstein cows. J. Dairy Sci. 92:3825-3832.

Doreau, M., Y. Chilliard, H. Rulquin, and D. I. Demeyer. 1999. Manipulation of milk fat in dairy cows. Pages 81-109 in Recent Advances in Animal Nutrition (Ed. P. C. Garnsworthy and J. Wiseman). Nottingham Press, Nottingham, UK.

Faldet, M. A., T. Nalsen, L. J. Bush, and G. D. Adams. 1989. Utilization of wheat in complete rations for lactating cows. J. Dairy Sci. 72:1243-1251.

Firkins, J. L. 1997. Effects of feeding nonforage fiber sources on site of fiber digestion. J. Dairy Sci. 80:1426-1437.

Gozho, G. N., and T. Mutsvangwa. 2008. Influence of carbohydrate source on ruminal fermentation characteristics, performance, and microbial protein synthesis in dairy cows. J. Dairy Sci. 91:2726-2735.

Huntington, G. B. 1997. Starch utilization by ruminants: from basics to the bunk. J. Anim. Sci. 75:852-867.

Jenkins, T. C. 1993. Lipid metabolism in the rumen. J. Dairy Sci. 76:3851-3863.

Khafipour, E. and D. O. Krause, and J. C. Plaizier. 2009. A grain- based subacute ruminal acidosis challenge causes translocation of lipopolysaccharide and triggers inflammation. J. Dairy Sci. 92:1060-1070.

Kolver, E., L. D. Muller, G. A. Varga, and T. J. Cassidy. 1998. Synchronization of ruminal degradation of supplemental carbohydrate with pasture nitrogen in lactating dairy cows. J. Dairy Sci. 81:2017-2028.

Krause, K. M., and G. R. Oetzel. 2006. Understanding and preventing subacute ruminal acidosis in dairy herds: A review. Anim. Feed Sci. Technol. 126:215-236.

Lammers, B. P., D. R. Buckmaster, and A. J. Heinrichs. 1996. A simple method for the analysis of particle sizes of forage and total mixed rations. J. Dairy Sci. 79:922-928.

Lechartier, C., and J. L. Peyraud. 2010. The effects of forage proportion and rapidly degradable dry matter from concentrate on ruminal digestion in dairy cows fed corn silage-based diets with fixed neutral detergent fiber and starch contents. J. Dairy Sci. 93:666-681.

Lechartier, C., and J. L. Peyraud. 2011. The effects of starch and rapidly degradable dry matter from concentrate on ruminal digestion in dairy cows fed corn silage-based diets with fixed forage proportion. J. Dairy Sci. 94:2440-2454.

Leddin, C. M., C. R. Stockdale, J. Hill, J. W. Heard, and P. T. Doyle. 2009. Increasing amounts of crushed wheat fed with pasture hay reduced dietary fiber digestibility in lactating dairy cows. J. Dairy Sci. 92:2747-2757.

Martin, C., C. Philippeau, and B. Michalet-Doreau. 1999. Effect of wheat and corn variety on fiber digestion in beef steers fed high-grain diets. J. Anim. Sci. 77:2269-2278.

National Research Council (NRC). 2001. Nutrient requirements of dairy cattle. 7th rev. ed. National Academy Press, Washington, DC, USA.

Nikkhah, A., F. Ehsanbakhsh, D. Zahmatkesh, and H. Amanlou. 2010. Prepartal wheat grain feeding improves energy and calcium status of periparturient Holstein heifers. Animal 5:522-527.

Orskov, E. R. 1986. Starch digestion and utilization in ruminants. J. Anim. Sci. 63:1624-1633.

Plaizier, J. C., J. E. Keunen, J. P. Walton, T. F. Duffield, and B. W. McBride. 2001. Effect of subacute ruminal acidosis on in situ digestion of mixed hay in lactating dairy cows. Can. J. Anim. Sci. 81:421-423.

Roche, J. R., A. J. Sheahan, L. M. Chagas, and R. C. Boston. 2008. Short communication: change in plasma ghrelin in dairy cows following an intravenous glucose challenge. J. Dairy Sci. 91:1005-1010.

Russell, J. B. 1998. The importance of $\mathrm{pH}$ in the regulation of ruminal acetate to propionate ratio and methane production in vitro. J. Dairy Sci. 81:3222-3230.

Stensig, T. and M. R. Weisbjerg, and T. Hvelplund. 1998. Digestion and passage kinetics of fibre in dairy cows as affected by the proportion of wheat starch or sucrose in the diet. Acta Agric. Scand. A. Anim. Sci. 48:129-140.

Tyrrell, H. F., and J. T. Reid. 1965. Prediction of the energy value of cow's milk. J. Dairy Sci. 48:1215-1223.

Van Keulen, J., and B. A. Young. 1977. Evaluation of acidinsoluble ash as a natural marker in ruminant digestibility studies. J. Anim. Sci. 44:282-287. 
Van Knegsel, A., H. Van den Brand, E. Graat, J. Dijkstra, R.
Jorritsma, E. Decuypere, S. Tamminga, and B. Kemp. 2007. Dietary energy source in dairy cows in early lactation: metabolites and metabolic hormones. J. Dairy Sci. 90:14771485.

Van Soest, P. J., J. B. Robertson, and B. A. Lewis. 1991. Methods for dietary fiber, neutral detergent fiber, and nonstarch polysaccharides in relation to animal nutrition. J. Dairy Sci. 74:3583-3597.

Wadhwa, D., N. F. G. Beck, L. P. Borgida, M. S. Dhanoa, and R. J. Dewhurst. 2001. Development of a simple in vitro assay for estimating net rumen acid load from diet ingredients. J. Dairy Sci. 84:1109-1117.
Weimer, P. J., D. M. Stevenson, and D. R. Mertens. 2010. Shifts in bacterial community composition in the rumen of lactating dairy cows under milk fat-depressing conditions. J. Dairy Sci. 93:265-278.

Zebeli, Q., S. M. Dunn, and B. N. Ametaj. 2011. Perturbations of plasma metabolites correlated with the rise of rumen endotoxin in dairy cows fed diets rich in easily degradable carbohydrates. J. Dairy Sci. 94:2374-2382.

Zhong, R. Z., J. G. Li, Y. X. Gao, Z. L. Tan, and G. P. Ren. 2008. Effects of substitution of different levels of steam-flaked corn for finely ground corn on lactation and digestion in early lactation dairy cows. J. Dairy Sci. 91:3931-3937. 